\title{
PENGARUH KEBISINGAN MESIN LAS DISEL LISTRIK TERHADAP FUNGSI PENDENGARAN PADA PEKERJA BENGKEL LAS DI KECAMATAN MAPANGET KOTA MANADO
}

\author{
${ }^{1}$ Ivana Anggelia Koagouw \\ ${ }^{2}$ Wenny Supit \\ ${ }^{3}$ Jimmy F Rumampuk
${ }^{1}$ Kandidat Skripsi Fakultas Kedokteran Universitas Sam Ratulangi
${ }^{2}$ Bagian Fisika Fakultas Kedokteran Universitas Sam Ratulangi
Email: ivanaanggelia@yahoo.co.id

\begin{abstract}
Abstrac: Noise is unwanted sound such as noise that comes from. Noise at high intensity that long exposes to people can cause interference both on auditory and also on non-auditory functions. The purpose of this study is to determine the effect of noise diesel electric welding machine to the auditory function, both subjective and objective. This research is an analytic survey with a cross-sectional design. The Population samples are from 30 people that wasobtained through questionnaire. Then performedin the examinationofauditory function using audiometer in Prof. dr.R. DKandou General Hospital Manado. Previous measurement of noise levels welding workshop conducted by measuring the Sound Level Meter. Data were analyzed using the Statistical Product and Service Solution Program (SPSS) and using Fisher's Exact test.The results show that workers with exposure noise $>90 \mathrm{~dB}$, a total of 27 workers with a percentage $(90 \%)$ have hearing loss and 3 workers with the percentage (10\%) do not hearing loss. Analytical results obtained by Fisher's Exact show that there is a significant relationship between the effect of noise on hearing function $(p=0,002)$. Conclusion: Based on these results it can be concluded, that there is a significant relationship between the effect of noise on significan hearing function.
\end{abstract}

Key Words: Noise, Hearing Function

Abstrak: Kebisingan adalah suara yang tidak dikehendaki seperti suara yang bersumber dari
bising mesin las disel listrik. Kebisingan pada intensitas tinggi dan dipaparkan dengan jangka
waktu yang lama pada orang dapat menimbulkan gangguan fungsi pendengaran dan juga pada
fungsi non pendengaran. Tujuan dari penelitian ini yaitu untuk mengetahui pengaruh kebisingan
mesin las disel listrik terhadap fungsi pendengaran, baik subjektif dan objektif.Penelitian ini
bersifat survey analitik dengan desain potong lintang.Populasi sebanyak 30 orang yang di peroleh
melalui kuesioner.Kemudian dilakukan fungsi pendengaran di RSUP. Prof. dr. R. D. Kandou
Manado yaitu pemeriksaan audiometer. Sebelumnya pengukuran tingkat kebisingan bengkel las
dilakukan dengan pengukuran Sound Level Meter. Data dianalisis dengan menggunakan
Statistical Program Product and Service Solution (SPSS) dan menggunakan uji Fisher Exact.
Hasil penelitian menunjukkan bahwa sebanyak 27 pekerja mengalami paparan kebisingan $90 \mathrm{~dB}$,
dengan presentrase (90\%) mengalami gangguan pendengaran dan 3 pekerja (10\%) tidak 
mengalami gangguan pendengaran. Hasil analisis Fisher Exact menyatakan terdapat hubungan yang signifikan antara pengaruh kebisingan terhadap fungsi pendengaran $(p=0,002)$. Simpulan: Berdasarkan hasil penelitian maka dapat disimpulkan bahwa ada hubungan yang signifikan antara pengaruh kebisingan terhadap fungsi pendengaran.

Kata Kunci : Kebisingan, Fungsi Pendengaran

Perkembangan dunia industri dewasa ini membawa suatu perubahan terhadap perekonomian negara maupun terhadap kesejahteraan pekerja. Penggunaan peralatan yang modern di satu sisi akan memberi kemudahan terhadap proses produksi dan produktivitas pekerja. Akan tetapi di sisi lainnya memiliki kemungkinan untuk meningkatkan resiko keselamatan dan kesehatan pekerja yang timbul akibat hubungan kerja. ${ }^{1}$

Banyak aktivitas kerja yang dapat dilakukan.Salah satunya yaitu membuat pagar besi.Pembuatan pagar dapat dilakukan dengan menggunakan mesin las disel listrik.Pagar besi yang indah mempunyai kepuasan tersendiri bagi pekerja. Akan tetapi, penggunaan mesin ini mempunyai dampak yang tidak baik yaitu tingkat kebisingan yang cukup tinggi. ${ }^{2,3}$

Kebisingan dari peralatan kerja maupun lingkungan tempat kerja merupakan salah satu faktor fisik yang berpengaruh terhadap keselamatan kerja. ${ }^{4}$ Gangguan yang ditimbulkan oleh kebisingan pada mesin las antara lain gangguan saat mendengar, gangguan dalam berkomunikasi dan gangguan pada saat berkonsentrasi. ${ }^{3,5}$

Gangguan pendengaran akibat bising (noise induced hearing loss / NHL) ialah gangguan pendengaran yang disebabkan akibat terpajan oleh bising yang cukup keras dalam jangka waktu yang cukup lama dan biasanya diakibatkan oleh bising lingkungan kerja. Secara umum bising adalah bunyi yang tidak diinginkan. ${ }^{3}$ Bising ini memiliki intensitas 85 desibel $(\mathrm{dB})$ atau lebih sehingga dapat menyebabkan kerusakan reseptor Corti pada telinga dalam. Sifat ketuliannya yaitu tuli saraf cochlea dan biasanya terjadi pada kedua telinga. ${ }^{3,6}$ Banyak hal yang mempermudah seseorang menjadi tuli akibat terpapar bising antara lain intensitas bising yang lebih tinggi, berfrekuensi tinggi, lebih lama terpapar bising,kepekaan individu dan faktor lain yang dapat menimbulkan ketulian. ${ }^{6,7}$

Gangguan kebisingan sangat bertentangan dengan prisip ergonomi. ${ }^{8}$ Ergonomi merupakan suatu cabang ilmu yang sistematis untuk memanfaatkan informasiinformasi mengenai sifat, kemampuan dan keterbatasan manusia merancang suatu sistem kerja, sehingga manusia dapat hidup dan bekerja pada sistem itu dengan baik, yaitu mencapai tujuan yang diinginkan melalui pekerjaan dengan efektif, aman dan nyaman. ${ }^{9}$ Permasalahan ergonomi merupakan salah satu faktor yang dapat menyebabkan turunya hasil produksi, hilangnya jam kerja, tingginya biaya pengobatan dan material, rendahnya kualitas kerja, meningkatnya kemungkinan terjadinya kecelakaan kerja. ${ }^{10}$

Data World Health Organization (WHO) mengenai angka gangguan pendengaran dan ketulian sungguh mengejutkan. Pada tahun 2000 terdapat 250 juta (4,2\%) penduduk dunia yang menderita gangguan pendengaran dan lebih kurang setengahnya (75-140 juta) terdapat di Asia Tenggara yang mempunyai prevalensi ketulian cukup tinggi yaitu 4,6\% termasuk Indonesia, angka ini meningkat terus. ${ }^{11}$

Data Indonesia berdasarkan Survei Kesehatan Indera Penglihatan dan Pendengaran tahun 1994-1996 juga menunjukan morbiditas yang tinggi mencapai $38,6 \%$, penyakit telinga adalah $18.5 \%$, prevalensi gangguan pendengaran adalah $16,8 \%$ sedangkan ketulian didapatkan pada $0,4 . \%{ }^{11,12}$

Berdasarkan uraian yang diatas, peneliti tertarik untuk melakukan penelitian dengan judul "Pengaruh Kebisingan Mesin Las Disel 
Listrik Terhadap Fungsi Pendengaran pada Pekerja Bengkel Las di Kecematan Mapanget Kota Manado”, yang kemungkinan besar ada kecenderungan terkena gangguan pendengaran akibat kebisingan mesin las disel listrik.

\section{METODE PENELITIAN}

Jenis Penelitian yang digunakan yaitu penelitian yang bersifat survey analitik dengan menggunakan desain potong lintang (Cross Sectional), dimana pengukuran hanya dilakukan hanya satu kali pada satu saat dari populasi di wilayah atau daerah. ${ }^{13}$ Penelitian ini dilakukan di Kecamatan Mapanget pada bulan Oktober-Desember 2012. Sampel yang digunakan yaitu pekerja bengkel las di Kecamatan Mapanget yang berusia 20-60 tahun yang bersedia ikut serta dalam penelitian dengan mendatangani informed consent, mengisi kuesioner dan melakukan pemeriksaan audiometer di Poliklinik THT BLU RSUP. Prof. Kandou. Untuk menjelaskan pengaruh kebisingan mesin las disel listrik terhadap fungsi pendengaran pada pekerja bengkel las, untuk menganalisa karakteristik (umur, lama bekerja, frekuensi menggunakan mesin dalam hari per minggu, rata-rata menggunakan mesin dalam jam perhari, ada atau tidak gangguan pendengaran, ada atau tidak penggunakan alat keselamatan) pekerja bengkel las di Kecamatan Mapanget, dan untuk menganalisa pengaruh intensitas kebisingan terhadap fungsi pendengaran pada pekerja bengkel las di Kecamatan Mapanget.

\section{HASIL PENELITIAN}

Berdasarkan data usia yang diambil secara subjektif dengan menggunakan kuesioner sebelum dilaksanakan pemeriksaan yang lebih lanjut, sebanyak 30 orang (100\%) tidak ada gangguan pendengaran. Terbanyak pada kelompok usia 20-35 tahun (40\%) didapatkan juga 12 subjek yang tidak ada gangguan pendengaran. Pada kelompok usia>35 tahun (60\%) dimana didapatkan 18 subjek yang tidak ada gangguan pendengaran (Tabel 1). Setelah dilakukan pemeriksaan menggunakan audiometer didapatkan hasil, yang mengalami gangguan pendengaran terbanyak terdapat pada usia >35 tahun dimana terdapat 23 orang pekerja yang mengalami gangguan pendengaran dengan jumlah prensentasi 76,7\% (Tabel 2).

Berdasarkan data lama bekerja sebangai pekerja bengkel las, gangguan pendengaran terbanyak pada kelompok yang telah berprofesi sebagai pekerja bengkel las selama 11-20 tahun dengan jumlah sampel sebanyak 18 orang dengan prensentase $60 \%$ (Tabel 3).

Berdasarkan data frekuensinya 3-6 hari seminggu bekerja, memiliki gangguan terbanyak dengan jumlah 26 orang dan dengan presentase sebanyak 86,7\%, serta dalam kelompok ini tidak di temukannya pekerja yang tidak mengalami gangguan pendengaran, dibandingkan dengan frekuensi bekerja $<3$ hari dan $>6$ hari (Tabel 4 ).

Berdasarkan data frekuensi kerja dalam sehari, didapatkan hasil pekerja yang mengalami gangguan pendengaran terbanyak yaitu kelompok pekerja yang frekuensi bekerjanya 4-8 jam sebanyak 80\%. Kemudian gangguan pendengaran terbanyak diikuti kelompok yang frekuensi bekerjanya lebih dari 8 jamperhari dengan jumlah presentase sebanyak 6,67 \% (tabel 5).

Berdasarkan data penggunaan alat keselamatan menunjukkan bahwa gangguan pendengaran terdapat pada pekerja yang tidak menggunakan alat keselamatan sebanyak 27 orang dengan presentase $90 \%$, dan sebanyak 3 orang tidak mengalami gangguan pendengaran dengan presentase $10 \%$ (Tabel 6).

Berdasarkan data intensitas bunyi (dB) dan hasil pemeriksaan fungsi pendengaran didapatkan 90-95 dB sebanyak 16,7\% sedangkan 95-100 sebanyak 83,3\%. Hasil Fisher Exact Test didapatkan p $=0,002$ (Tabel 7). 
382 Jurnal e-Biomedik (eBM), Volume 1, Nomor 1, Maret 2013, hlm. 379-386

Tabel 1. Distribusi Hasil Berdasarkan Usia Pekerja Secara Subjektif

\begin{tabular}{cccccccc}
\hline No & $\begin{array}{c}\text { Kelompok } \\
\text { Usia }\end{array}$ & $\begin{array}{c}\text { Ada } \\
\text { gangguan } \\
\text { pendengaran }\end{array}$ & $\%$ & $\begin{array}{c}\text { Tidak ada } \\
\text { gangguan } \\
\text { pendengaran }\end{array}$ & $\%$ & \multicolumn{2}{c}{ Total } \\
\cline { 7 - 9 } & $<20$ tahun & 0 & 0 & 0 & 0 & 0 & 0 \\
\hline 1 & 0 & 0 & 12 & 40 & 12 & 40 \\
2 & $20-35$ tahun & 0 & 0 & 18 & 60 & 18 & 60 \\
\hline 3 & $>35$ tahun & 0 & 0 & 30 & 10 & 30 & 100 \\
\hline
\end{tabular}

Tabel 2. Distribusi hasil pemeriksaan fungsi pendengaran berdasarkan usia

\begin{tabular}{ccccccccc}
\hline No & $\begin{array}{c}\text { Kelompok } \\
\text { Usia }\end{array}$ & $\begin{array}{c}\text { Ada } \\
\text { gangguan } \\
\text { pendengaran }\end{array}$ & $\%$ & $\begin{array}{c}\text { Tidak ada } \\
\text { gangguan } \\
\text { pendengaran }\end{array}$ & $\%$ & \multicolumn{2}{c}{ Total } & \\
\hline 1 & $<20$ thn & 0 & 0 & 0 & 0 & 0 & 0 \\
2 & $20-35$ thn & 4 & 13,3 & 3 & 10 & 7 & 23,3 \\
3 & $>35$ thn & 23 & 76,7 & 0 & 0 & 23 & 76,7 \\
\hline & Total & 0 & 90 & 30 & 10 & 30 & 100 \\
\hline
\end{tabular}

Tabel 3. Distribusi hasil pemeriksaan fungsi pendengaran lama bekerja

\begin{tabular}{ccccccc}
\hline \multirow{2}{*}{$\begin{array}{c}\text { Kategori Lama } \\
\text { Bekerja (Tahun) }\end{array}$} & \multicolumn{3}{c}{$\begin{array}{c}\text { Hasil Pemeriksaan } \\
\text { Fungsi Pendengaran }\end{array}$} & \multicolumn{3}{c}{ Total } \\
\cline { 2 - 7 } & Gangguan & $\%$ & Normal & \% & Jumlah & $\%$ \\
\hline$<10$ tahun & 6 & 20 & 3 & 10 & 9 & 30 \\
$11-20$ tahun & 18 & 60 & 0 & 0 & 18 & 60 \\
$>20$ tahun & 3 & 10 & 0 & 0 & 3 & 10 \\
\hline Total & 27 & 90 & 3 & 10 & 30 & 100 \\
\hline
\end{tabular}


Tabel 4. Distribusi hasil pemeriksaan fungsi pendengaran berdasarkan frekuensi bekerja (hari) dalam seminggu

\begin{tabular}{cccccccc}
\hline $\begin{array}{c}\text { Kategori Frekuensi } \\
\text { Bekerja Seminggu (Hari) }\end{array}$ & \multicolumn{3}{c}{$\begin{array}{c}\text { Hasil Pemeriksaan Fungsi } \\
\text { Pendengaran }\end{array}$} & \multicolumn{3}{c}{ Total } \\
\cline { 2 - 8 } & Gangguan & $\%$ & Normal & $\%$ & Jumlah & $\%$ \\
\hline$<3$ hari & 0 & 0 & 0 & 0 & 0 & 0 \\
$3-6$ hari & 26 & 8,7 & 3 & 10 & 29 & 9,7 \\
$>6$ hari & 1 & 3,3 & 0 & 0 & 1 & 3,3 \\
\hline Total & 27 & 90 & 3 & 10 & 30 & 100 \\
\hline
\end{tabular}

Tabel 5. Distribusi hasil pemeriksaan fungsi pendengaran berdasarkan frekuensi bekerja (jam) dalam sehari

\begin{tabular}{cccccccc}
\hline \multirow{2}{*}{$\begin{array}{c}\text { Kategori Frekuensi Kerja } \\
\text { Sehari (Jam) }\end{array}$} & \multicolumn{3}{c}{$\begin{array}{c}\text { Hasil Pemeriksaan Fungsi } \\
\text { Pendengaran }\end{array}$} & \multicolumn{2}{c}{ Total } \\
\cline { 2 - 8 } & Gangguan & $\%$ & Normal & $\%$ & Jumlah & $\%$ \\
\hline$<4$ jam & 1 & 3,3 & 0 & 0 & 1 & 3,3 \\
$4-8$ jam & 24 & 80 & 2 & 6,7 & 26 & 8,7 \\
$>8$ jam & 2 & 6,7 & 1 & 3,3 & 3 & 10 \\
\hline Total & 27 & 90 & 3 & 10 & 30 & 100 \\
\hline
\end{tabular}

Tabel 8. Distribusi hasil pemeriksaan fungsi pendengaran berdasarkan ada atau tidak mengguanakan alat keselamatan (pelindung telinga)

\begin{tabular}{|c|c|c|c|c|c|c|}
\hline \multirow[t]{2}{*}{$\begin{array}{c}\text { Pengguanaan Alat Keselamatan } \\
\text { (Pelindung Telinga) }\end{array}$} & \multicolumn{3}{|c|}{$\begin{array}{c}\text { Hasil Pemeriksaan Fungsi } \\
\text { Pendengaran }\end{array}$} & \multicolumn{3}{|c|}{ Total } \\
\hline & Gangguan & $\%$ & $\begin{array}{l}\text { Norm } \\
\text { al }\end{array}$ & $\%$ & Jumlah & $\%$ \\
\hline Menggunakan & 0 & 0 & 0 & 0 & 0 & 0 \\
\hline Tidak menggunakan & 27 & 90 & 3 & 10 & 30 & 100 \\
\hline Total & 27 & 90 & 3 & 10 & 30 & 100 \\
\hline
\end{tabular}

Tabel 9.Distribusi Intensitas bunyi (dB) dan Hasil pemeriksaan fungsi pendengaran 


\begin{tabular}{|c|c|c|c|c|c|c|c|}
\hline \multirow{2}{*}{$\begin{array}{c}\text { Intensitas Bunyi } \\
\text { (dB) }\end{array}$} & \multicolumn{3}{|c|}{$\begin{array}{c}\text { Gangguan Pendengaran } \\
\text { Telinga }\end{array}$} & \multicolumn{3}{|c|}{ Total } & \multirow[t]{2}{*}{$\begin{array}{c}\text { Fisher } \\
\text { Exact Test }\end{array}$} \\
\hline & Gangguan & $\%$ & Normal & $\%$ & Jumlah & $\%$ & \\
\hline $90-95$ & 2 & 6,7 & 3 & 10 & 5 & 16,7 & 0,002 \\
\hline 96-100 & 25 & 8,3 & 0 & 0 & 25 & 83,3 & \\
\hline Total & 27 & 90 & 3 & 10 & 30 & 100 & \\
\hline
\end{tabular}

\section{BAHASAN}

Hasil penelitian menyatakan bahwa kelompok usia produktif yang banyak mengalami gangguan pendengaran yang dikelompokkan yang berusia $>35$ thn dengan presentase 76,7\%. Arini EY dalam penelitiannya mendapatkan bahwa pekerja yang berusia 30-40 tahun dengan presentase $58,3 \%$ berisiko mengalami gangguan pendengaran tipe sensorineural pada Unit Produksi di PT. Kurnia Jati Utama. ${ }^{14}$

Menggunakan mesin las disel listrik dalam jangka waktu yang lama, maka akan semakin besar dampak yang akan dialami oleh pekerja. Menurut hasil penelitian gangguan pendengaran yang cukup tinggi, terdapat kelompok yang berprofesi sebagai pekerja bengkel las yang sudah bekerja selama >11 tahun sebanyak 21 subjek dengan presentase total yang mengalami gangguan sebanyak 70\%. Hal ini membuktikan bahwa pajanan dalam jangka waktu lama (tahun), menurut teori lebih dari 5 tahun terpapar bising dapat menyebabkan gangguan poendengaran. ${ }^{3}$ Apabila dilihat dari frekuensi bekerja selama seminggu, maka pekerja yang frekuensi bekerja $>3$ hari seminggu memiliki gangguan pendengaran yang terbanyak dengan presentase $90 \%$ dibandingkan frekunsi bekerja $<3$ hari seminggu, sedangkan dilihat dari frekuensi bekerja dalam sehari, didapatkan pekerja pada kelompok $>4$ jam banyak mendapat gangguan pendengaran dengan presentase $86,7 \%$. Dari hasil penelitian tersebut menyebutkan bahwa semakin lama menggunakan mesin disel las listrik besi maka berisiko mendapat gangguan pendengaran lebih besar. ${ }^{6}$

Pemakaian alat pelindung telinga merupakan salah satu cara uintuk mengurangi besarnya paparan intensitas kebisingan terhadap pekerja. ${ }^{15}$ Dari hasil penelitian ditemukan 100\% pekerja bengkel las tidak menggunakan alat keselamatan (pelindung telinga) dengan presentase 90\%.

Pajanan bising yang dianggap cukup aman adalah pajanan sehari dengan intensitas tidak melebihi 85 dB selama 8 jam sehari atau 40 jam seminggu. Jika melebihi batas yang diperkenankan maka akan timbul gangguan pendengaran. ${ }^{16}$ Menurut hasil penelitian ditemukan bahwa intensitas 90$100 \mathrm{~dB}(>85 \mathrm{~dB})$ dengan frekuensi bekerja $>4$ jam sehari.

Pada pengukuran fungsi pendengaran dengan menggunakan alat audiometer didapatkan 3 orang pekerja tidak memiliki gangguan pendengaran dengan presentase sebanyak $10 \%$ dan 27 orang pekerja mengalami gangguan pendengaran dengan presentase sebanyak 90\%. Pada intensitas bunyi didapatkan 90-100 dB. Tingkat 
ketulian ditentukan dengan menggunakan kriteria ISO (International Standard Organization) yang ukuran normalnya 0-25 dB. ${ }^{12}$

Berdasarkan hasil pada penelitian ini, didapatkan adanya hubungan yang bermakna antara pengaruh intensitas bunyi dengan fungsi pendengaranpada pekerja bengkel las, karena uji fisher exact testdi dapatkan nilai $p=0,002(p=<0,05)$.

\section{SIMPULAN}

Dari penelitian ini menunjukkan hasil signifikan ( $p=<0,05)$, yang menyatakan adanya pengaruh dalam hubungan intensitas kebisingan dengan fungsi pendengaran.

\section{SARAN}

Dibutuhkan penelitian lebih lanjut untuk mengetahui hubungan yang signifikan, dan juga pengaruh lama pajanan kebisingan terhadap pekerja yang menggunakan mesin las disel listrik.Bagi pekerja yang bekerja pada tingkat kebisingan $>85 \mathrm{~dB}$ disarankan menggunakan alat pelindung keselamatan.Dan perlu diadakan penyuluhan dan sosialisasi tentang pengaruh kebisingan terhadap kesehatan dan keselamatan kerja pada pekerja bengkel las.

\section{UCAPAN TERIMA KASIH}

Terima kasih kepada dr. Wenny Supit, MRepro, SpAnd dan dr. Jimmy F. Rumampuk, MKes, AIFO yang telah memberikan saran/masukan yang sangat bermanfaat dalam penyelesaian penelitian ini. Dan juga tak lupa semua pihak yang secara langsung ataupun tidak langsung telah menumbuhkan gagasan dalam artikel ini.

\section{DAFTAR PUSTAKA}

1. Hidayah NY, Dlenlyah L, Wulandhari R. Analisis Pengaruh Faktor Kebisingan Dan Tingkat Kesulitan Kerja Terhadap
Produktivitas Line Assembling PT. X. Jurusan Teknik Industri Fakutas Teknik Universitas pancasila. 2008; 1.

2. Hotniar P. Learning Process Of Production Women Shirt At PD. Sonatajaya. Jurusan Teknik Industri Fakultas Teknik Universitas Gunadarma. 2003; 3

3. Christopher AP. Noise Induced Hearing Loss (NIHL) (disertasi). Fakultas Kedokteran Universitas Riau. 2009; 1-17.

4. Masykuri M, Harjana I, Yahya I, Legowo B, et al. Teknologi PengendalianKebisingan Menggunakan DesainOpened-Cell Polyurethane Foam (Ocpf). Program Studi Kimia PMIPA FKIP Dan Jurusan Fisika FMIPA Universitas Sebelas Maret. 2012; 45.

5. Tak NRM, Rumajar PD. Gambaran Tingkat Ketulian Tenaga Kerja Ruang Mesin PLTA Sektor Minahasa Wilayah Suluttenggo. Fakultas Kesehatan Masyarakat Universitas Sam Ratulangi Manado Dan Politeknik Kementrian Kesehatan Manado. 2012; 37.

6. Rambe AYM. Gangguan Pendengaran Akibat Bising. Bagian Ilmu Penyakit Telinga Hidung Tenggorokan Fakultas Kedokteran Universitas Sumatera Utara. 2003; 1-6.

7. Luxson M, Darlina S, Makala $\mathbf{T}$. Kebisingan Di Tempat Kerja. Program Pasca Sarjana Kesehatan Masyarakat STIK Bina Husada Palembang. 2010; 76-85.

8. Hartoro S. Analisis Tingkat Kebisingan di Departement Permesinan dan Fabrikasi. Fakultas Teknik Universitas Negeri Yogyakarta. 2003; 122.

9. Wignjosoebroto S, Gunani S, Pawennari A. Analisis Ergonomi Terhadap Rancangan Fasilitas Kerja Pada Stasiun Kerja Di Bagian Skiving Dengan Antropometri Orang Indonesia (Studi Kasus Di Pabrik Vulkanisir Ban).2010; 1 
10. Asril AS. Industri Informal Pada Usaha Penjahitan. Kesehatan Masyarakat Fakultas Ilmu Kesehatan Universitas Islam Negeri Alauudin Makasar. 2012;1.

11. Soetjipto D.Selayang Pandang Komite Nasional Penanggulangan Gangguan Pendengaran Dan Ketulian (KOMNAS PGP Ketulian). Diakses: 03 Desember 2007

12. Adam GL, Boies LR, Higler PA. Fakultas Kedokteran Indonesia. Buku Ajar Penyakit THT Edisi 6. Penerbit Buku Kedokteran EGC. Jakarta: 1997; 27-119

13. Sastroasmoro S, Ismael S. Dasar-Dasar Metedologi Penelitian Klinis. Edisi ke-4; 2011. 130-145

14. Arini AY. Faktor-Faktor Yang Berhubungan Dengan Gangguan Pendengaran Tipe Sensorineural Tenaga
Kerja Unit Produksi Di PT. Kurnia Jati Utama Semarang (disertasi). 2005; 55

15. Bashiruddin J. Program Konservasi Pendengaran Pada Pekerja Yang Terpajan Bising Industri. Departemen Telinga Hidung Tenggorokkan Fakultas Kedokteran Universitas Indonesia. Majalah Kedokteran Indonesia, Volume: 59, Nomor: 1 ; Januari 2009.

16. Susilawati NK. Sudana W, Setiawan EP. Pengaruh Bising Lalu Lintas Terhadap Penurunan Fungsi Pendengaran Pada Juru Parkir Di Kota Denpasar (Laporan Penelitian). Departemen Ilmu Penyakit Telinga Hidung Tenggorok Fakultas Kedokteran Universitas Udayana Rumah Sakit Sanglah Denpasar Bali-Indonesia. 2011;2 